\title{
UN EPISODIO EN LA VIDA DE JUANA DE LA CRUZ: SOBRE LA AUTORIDAD ESPIRITUAL FEMENINA A COMIENZOS DEL SIGLO XVI ${ }^{1}$
}

\author{
Rebeca Sanmartín Bastida \\ Universidad Complutense de Madrid - ITEM \\ rebecasb@ucm.es
}

L

as visionarias castellanas que escriben al final del siglo XV y comienzos del siglo XVI se han estudiado desde aproximaciones feministas que han tenido como punto de partida la división binaria del género representada en sus palabras, pero existen otras maneras de otorgar autoridad a estas mujeres que no implican un entendimiento diferenciado de los sexos ${ }^{2}$. Una de esas maneras, como voy a proponer aquí, es la relación que mantienen con los objetos, en concreto con las artes visuales, un aspecto que se ha estudiado muy poco a diferencia de lo que sucede con otras comunidades femeninas europeas. Este olvido es un error que debemos subsanar porque la relación entre las imágenes y las beatas visionarias que triunfaron en la época de los Reyes Católicos y Carlos V, es decir, en tiempos de la Reforma, nos proporciona pistas esenciales sobre la emergencia de la autoridad espiritual femenina en Castilla, antes de santa Teresa, cuando desde el beaterio accedieron a la esfera pública y alcanzaron liderazgo religioso. Y lo hicieron en una región con unas circunstancias particulares que no encontramos en otras partes de Europa, en concreto en una sociedad donde todavía existían en conflicto diversas razas y religiones, un hecho que debemos tener en cuenta, junto

$1 \quad$ Este artículo se ha desarrollado dentro del proyecto «La conformación de la autoridad espiritual femenina en Castilla» (FFI2015-63625-C2-2-P; 2016-2019), I+D de Excelencia del Ministerio de Economía y Competividad (MINECO), financiado por la Agencia Estatal de Investigación (AEI) y el Fondo Europeo de Desarrollo Regional (FEDER, UE); y del grupo de investigación «Literatura, heterodoxia y marginación» (970747) de la Universidad Complutense de Madrid. Agradezco a María Jesús Zamora el haberme invitado a formar parte de este volumen.

2 Véanse, como muestra de esta perspectiva, los sugerentes trabajos de Graña Cid (2004, 2009), Cruz (2005) y Muñoz Fernández (2014a y b).

Edad de Oro, XXXVIII (2019), pp. 55-73, ISSN: 0212-0429 - ISSNe: 2605-3314

DOI http://doi.org/10.15366/edadoro2019.38.003 
con las corrientes espirituales heterodoxas que empezaban a surgir por entonces, al abordar las performances visionarias que protagonizan (Sanmartín Bastida 2012: 241-289).

En este artículo voy a tratar este asunto refiriéndome a Juana de la Cruz (1481-1534), quien, junto a María de Ajofrín (?-1489), María de Santo Domingo (¿1486?-1524) y otras beatas visionarias, adquirió fama de «santa viva», es decir, formó parte de un grupo de mujeres que siguieron un modelo de santidad basado en el ayuno extremo, la penitencia radical, los éxtasis eucarísticos y, sobre todo, carismas como estigmatizaciones y profecías que las dotaron de gran influencia en la corte, y cuyo principal paradigma fue Catalina de Siena ${ }^{3}$. Estas mujeres nos ayudan a entender las maneras a través de las cuales, en una sociedad mayoritariamente analfabeta, las imágenes, en su interacción con ellas durante los trances, alcanzan una distintiva agencia de poder ${ }^{4}$.

\section{IMÁGENES, MUJERES VISIONARIAS E INQUISICIÓN: \\ EL CASO DE JUANA DE LA CRUZ}

Las imágenes, además de enseñar a los fieles la doctrina (Duby 1995; Baschet 2008: 29), y ofrecer compañía a los religiosos en una vida llena de silencios (Jäggi 2014: 263), trasladan al espectador a otra realidad más alta y actúan como vías de trascendencia ${ }^{5}$. En este artículo, abordo a unas mujeres que tienen como uno de los puntos de partida del éxtasis la mirada al icono, empleado para cruzar la distancia y llegar a la divinidad. Así, en las hagiografías de María de Ajofrín o Juana de la Cruz se nos muestra explícitamente cómo el arte sirve de iniciación del trance, al igual que en otras ocasiones lo hace la música o la toma de la comunión. Y si los iconos inspiran el imaginario de sus visiones, como ya intenté demostrar en Sanmartín Bastida (2015), su contemplación las conecta con lo sagrado y les abre la puerta de la revelación.

3 «Santas vivas» es una expresión que emplea famosamente Gabriella Zarri (1990) para referirse a un movimiento «cateriniano» de mujeres italianas (la mayoría terciarias dominicas) que cobraron importancia con sus profecías imitando a Catalina de Siena, entre el final del Medievo y el inicio del siglo XVI. Para estudios introductorios sobre algunas de estas beatas castellanas, desde ópticas distintas, véase Muñoz Fernández (1994), Surtz (1995) y Braguier (2014).

4 Aunque no vamos a detenernos en este estema, para un estudio de la agencia del arte, que adquiere poder sobre sus contempladores, véase Gell (1998). En Sanmartín Bastida (en prensa) analizo detenidamente, y desde una perspectiva teórica, todas las implicaciones que tiene la interacción entre imágenes y visionarias.

5 Duby (1995: 8) subraya la cualidad mediadora de las imágenes, que favorecen la comunicación con el otro mundo. 
Las imágenes generan, entonces, trascendencia en la vida espiritual de estas mujeres. Sus visiones se relacionan dramáticamente con la iconografía de la época, la cual adquiere vida y modifica sus posturas iniciales tras completarse la interacción en el trance, durante el cual la visionaria se dirige a los seres celestiales representados en pinturas o esculturas ${ }^{6}$. No obstante, estas dos artes visuales no actúan de manera semejante en las revelaciones: hay una suerte de gradación, las esculturas se mueven más que las pinturas. Al tener más corporalidad, rasgo contra el cual advierte el muy difundido en el xvi Confesional del Tostado, porque las hace más sujetas a idolatría (Pereda 2007: 87 y 423), su mayor materialidad les otorga a su vez mayor movilidad y dinamismo: una mayor capacidad motriz que se hace llamativa en relatos medievales como las Cantigas de Santa María (García Avilés 2007), donde la capacidad de teletransportarse de la Virgen se pone continuamente en escena. Si desde el siglo XIII comienzan a proliferar las esculturas que muestran signos de estar animadas, algo que se extiende a los iconos de origen oriental, que se hicieron mayoritarias imágenes de culto (Mocholí Martínez 2016: 425-442; Belting 2009), a partir de finales del siglo Xv se abre una nueva etapa en el proceso de difusión de imágenes sagradas, que otorga más importancia a la prueba visual (frente a la verbal) de sus virtudes sobrenaturales, y que se ve refrendado por la popularidad de las imágenes marianas (Pereda 2007: 138)7.

En este artículo, quiero mostrar un ejemplo de la importancia de una escultura de la Virgen en un episodio acaecido a una famosa visionaria toledana, Juana de la Cruz, que adquirió gran fama en su época como santa viva, y que podría considerarse como la primera dramaturga en lengua castellana por los dos autos incluidos en el Libro de la casa, al que enseguida me referiré. Juana, terciaria franciscana del beaterio (luego convento) de Santa María de Cubas (sito entonces en Toledo y ahora en Madrid), tuvo una vida un tanto agitada en cuanto que tuvo que disfrazarse de hombre para escapar a un matrimonio no deseado, fue investida párroco, luego acusada de nepotismo, y durante un tiempo le prohibieron predicar en público, si bien salió de todo esto bien parada y murió con loores de santidad ${ }^{8}$. Coetánea de la controvertida beata dominica María de Santo Domingo, también visionaria y quien ha despertado un interés conjunto en varias historiadoras feministas, Juana sigue siendo bastante desconocida para muchos especialistas de la

\footnotetext{
$6 \quad$ Sobre el arte viviente, véase Freedberg 1992 (especialmente el capítulo 11). Para un estudio de sus efectos en las mujeres visionarias, véase Sanmartín Bastida (en prensa). Para el aspecto teatral de los sermones de Juana, véase Sanmartín Bastida (2012: 281-287).

7 Por otro lado, después del IV Concilio de Letrán (1215) en el icono aparece intensificado el pathos de la Virgen (Mocholí Martínez 2016: 434), dentro de una tendencia a otorgar mayor humanización a los seres celestiales.

8 Para un resumen breve de la biografía de la franciscana, véase Cortés Timoner (2004).
} 
temprana Edad Moderna, aunque seguramente esto cambie si se la consigue canonizar por confirmación de culto. Conocida en sus tiempos como «la santa Juana» (de ahí el título de la trilogía que Tirso de Molina compuso sobre su figura), a su celda acudían autoridades y personajes famosos de la corte como Cisneros, Fernando «el Católico», el Gran Capitán o Carlos V para verla y oírla, si bien no ha sido llevada a los altares por objeciones de tipo doctrinal al contenido de su libro de sermones visionarios: el Libro del conorte (circa 1509) $)^{9}$.

En este libro de sermones podemos encontrar una gran inspiración iconográfica, con un paraíso repleto de banquetes celestiales, danzas y ángeles músicos. Pero no es en este corpus en el que ahora nos vamos a fijar, sino en dos obras escritas en torno a esta figura y su comunidad de beatas (luego monjas) en el siglo Xvi: la Vida y fin de la bienabenturada virgen sancta Juana de la Cruz, hagiografía escrita por sus compañeras que se inició en vida de Juana (de hecho, gran parte es relatada por ella), con María Evangelista a la cabeza; y el Libro de la casa y monasterio de Nuestra Señora de la Cruz, donde se recoge algún episodio de su vida y oraciones y celebraciones suyas, todo ello junto con hechos milagrosos de su comunidad, por lo que fue compilado seguramente varios años después de su muerte (y sería posterior a la primera obra, aunque quizás María Evangelista colaboró).

En estos textos, Juana se inspira a menudo en la iconografía circundante, por ejemplo en su descripción del infierno y el purgatorio (Vida y fin, ff. $79 \mathrm{v}$ y 108r-v). Su representación de los bienaventurados a través de los instrumentos de sus martirios nos remite también a lo iconográfico, así como los vestidos que llevan los santos o los que referencian el cargo de un personaje (Vida y fin, ff. 63v y 77r; Juana de la Cruz 1999, II: 963-964 y 966; Luengo Balbás 2016: 257). En el Libro de la casa es constante la relación de familiaridad con las imágenes, favorecida porque las mujeres tejían trajes y vestidos para esculturas de altares y ermitas, y adornaban las imágenes en una devoción particularmente táctil. La relevancia que se otorga a esculturas y pinturas llama la atención: ya no solo de Cristo o de la Virgen, sino también de otros santos como santa Bárbara, santa Ana o Juan el Bautista, en un desfile de alusiones recurrente (véase Libro de la casa, ff. $48 \mathrm{v}-51 \mathrm{v}$ ), unas imágenes que Juana pudo observar y recomponer en sus revelaciones extáticas y que a veces hablan cobrando vida.

En la hagiografía se nos cuenta que durante sus sermones, que duraron trece años, Juana, a quien se depositaba en una cama cuando comenzaba el trance, adquiría un gesto hermoso y se sucedían a través de ella distintas voces, entre las

$9 \quad$ En 1558 se pide que se lleven al tribunal de la Inquisición de Madrid todas las copias de esta obra, a la que alcanzó la prohibición de difusión de sermones en romance del Índice inquisitorial de 1559. Aunque no hubo condena explícita del libro, un censor anónimo tachó y emborronó páginas y sermones enteros de la copia que se encontraba en San Juan de los Reyes de Toledo (García de Andrés 1999: 94-100). 
cuales se encontraba la del mismo Dios, produciéndose un cambio en el tono y timbre de sus palabras, en un proceso prolongado en el tiempo que podía durar varias horas y que acababa con su bendición (Vida y fin, ff. 27v-28r y $31 \mathrm{r}$; Libro de la casa, f. 20r): dada la capacidad locutiva de las imágenes, podemos también imaginar que este ejercicio de ventrilocuismo se extendía fácilmente a ellas ${ }^{10}$. Quienes asistían como público a sus revelaciones la verían interaccionar con las imágenes en sus visiones en un tiempo y espacio que al hacerse trascendentes se alejaban del cotidiano, en los que la visionaria presentaba algo que ella veía y que las personas que compartían su habitación eran incapaces de visionar. En esa revelación la palabra tenía poder creador porque, con su discurso, la visionaria no solo estaba llevando a los presentes a un lugar en el que ellos no se encontraban, sino que, al describir el movimiento de las imágenes, estaba completando el espacio que ocupaban juntos. Las visionarias veían actuar a las imágenes que el resto de personas observaban quietas, y hacían así asistir al desarrollo de una narración que solo estaba apuntada en el icono. Con ello, reavivarían el conocimiento del público de la historia sagrada a través de esas imágenes que adquirían vida. En la hagiografía se nos declara que en una visión en que Juana contempla una representación de san Juan con la Virgen, las dos Marías y Cristo al pie del calvario, este «por algún espaçio pareçe que está como vivo y mirando a quien le suplica con gesto alegre y bulto resplandeçiente e muy claro» (Vida y fin, f. 65v).

Por otro lado, y esto me interesa especialmente antes de dar paso al episodio que protagoniza Juana, las imágenes, durante este proceso de interacción con las mujeres, les otorgarían una autoridad espiritual muy valiosa en el momento. Primero, por el procedimiento de imitación, asunto del que ya me ocupé en Sanmartín Bastida (2015) y en el que ahora no me voy a detener. Baste decir que santas vivas como María de Ajofrín, María de Santo Domingo o Juana de la Cruz imitan con sus matrimonios y abrazos místicos las narraciones de santidad femenina que pudieron observar en pinturas. Segundo, y esto me interesa especialmente, por un proceso de igualación, del que me ocupo extensamente en Sanmartín Bastida (en prensa) y que aquí voy a resumir: se trata de un proceso en el que se fomenta un préstamo mutuo de poder y dominio. Si las imágenes ordenan y aconsejan a las visionarias en numerosos trances, también estas, en un momento dado, pueden autorizar la circulación de imágenes como si fueran sacerdotes (como comprobaremos enseguida), o santificar las ropas que les prestan actuando como iconos a la manera de María de Santo Domingo; y si en una visión se produce un movimiento en la imagen que da lugar a su modificación, como sucede en la vida de María de Ajofrín, las mujeres podrán consagrar este cambio que dotará de poder milagroso

10 Sobre el ventrilocuismo místico, donde la voz de Dios puede ocupar cuerpos no normativos, véase Hayes (2011), quien realiza su estudio partiendo de Connor (2000). 
a esa imagen, siempre dentro de una codificación gestual de la que famosamente nos puso sobre aviso Schmitt (1990) ${ }^{\mathbf{1 1}}$.

No obstante, clave para nuestro estudio es una última forma de autorización relacionada con la compleja sociedad castellana a la que he aludido al comienzo de este trabajo. Sabemos que la posesión y la veneración de las imágenes eran garantía de no sufrir sospechas de herejía o de prácticas judías, pues se consideraba una muestra de no ser judaizante ni converso, es decir, de ortodoxia: de ahí en parte el mercado de imágenes que surge por esas fechas ${ }^{\mathbf{1 2}}$. Si los judíos rechazaban la adoración cristiana de las imágenes, la Inquisición atrapaba a muchos criptojudíos y conversos con este pretexto: algunos no se habían convertido del todo porque, se aducía, faltaban imágenes en su poder o las tenían apartadas, unos argumentos inquisitoriales que muestra en su muy documentado libro Felipe Pereda (2007). Y esto se ha de poner en correlación con la política de distribución de imágenes que impulsan los Reyes Católicos (no sin resistencias), por ejemplo entre moriscos, porque las imágenes en la península ibérica estaban marcadas por los conflictos étnico-religiosos (Pereda 2007: 372) ${ }^{\mathbf{1 3}}$.

Frente a esta sospecha, las visionarias, consideradas santas vivas, y especialmente beligerantes con los conversos, se nos muestran como amantes de las imágenes. De este modo, además del apoyo otorgado a la Inquisición con unas visiones que delatan a los herejes, como las de María de Ajofrín (Vida de la bienabenturada virgen..., ff. 206r y 223v), o con sermones en los que moros, judíos y conversos sufrían diatribas, caso de los de María de Santo Domingo y Juana de la Cruz, que valieron a esta última ser calificada de «martillo de los herejes» (García de Andrés 1999: 104-105; Giles 1990: 9 y 36; Sastre Varas 2004: 178), las visionarias se aseguran su ortodoxia a través de las imágenes potenciando, al tiempo, su culto. Debemos recordar que algunas de estas mujeres estaban siendo criticadas por funciones sacerdotales como predicar, dar la absolución o escuchar en confesión, además de por encabezar programas reformistas apoyadas por Cisneros, caso de María de Santo Domingo y Juana de la Cruz. Desde luego, a Juana le interesaba parecer ortodoxa en un momento en que cierto tipo de franciscanismo

1 Hay un par de episodios de la Vida de la bienabenturada virgen María de Ajofrín donde se produce un movimiento de mano o de pie en la imagen que luego se consagra (ff. 194v, 217r-v).

12 Las Cantigas de Santa María (por ejemplo la 264) o Los milagros de Nuestra Señora de Berceo (el episodio del niño judío) nos muestran asumido este supuesto rechazo de judíos y musulmanes hacia las imágenes.

13 Según Pereda, «entre 1478 y 1501 la cultura de la imagen santa había emprendido el camino de un salto cualitativo, y que de la misma manera en que fue el conflicto entre las religiones el que determinó, o por lo menos aceleró, su nuevo rumbo, también la actitud hacia las imágenes de todos y cada uno de los protagonistas estuvo condicionada por el estamento socio-religioso del que procedían, ya fueran cristiano-viejos, judíos, moriscos o conversos» (2007: 372). 
era contemplado con sospecha, y la prueba de ello es su «denuncia» del profeta iluminista fray Melchor ${ }^{14}$.

En este sentido, hay que advertir que la nueva secta de los alumbrados (algunos de cuyos líderes procedían de familias conversas) rechazaba la adoración de las imágenes, a las que calificaban de «trozos de madera» (Santonja 2000: 360), al igual que más tarde pasará con los quietistas; así, el inquisidor Alonso Manrique de Lara atribuye al iluminismo hispánico, en su edicto de 1525 , la aserción de que «no se habían de reverenciar las imágenes de Cristo, ni de Nuestra Señora» (reprod. en Conde Solares 2017: 27), y en la relación contra las proposiciones de los alumbrados de Llerena de 1575 se acusa a las beatas de esta secta de que «no pueden ver imágenes» (reprod. en Santonja 2000: 388; véase también 361 y 364). Es posible que el episodio de la vida de Juana que vamos a referir se desarrollara cuando se denunciaban ante la Inquisición las primeras tendencias alumbradas, en la segunda década del siglo XVI, aunque ya antes, en 1512, había despuntado el citado iluminismo franciscano (Gómez López y García de Andrés 1982: 32).

De este modo, si en los juicios inquisitoriales la relación con el arte constituía un elemento clave para librarse o cargarse de acusaciones, las mujeres se ocupan de re-autorizar estos elementos del culto en sus revelaciones, como hacen también con sacramentos como la eucaristía (Elliot 2004: 1), recibiendo legitimidad al hacerlo y evitando sospechas de heterodoxia, que, en los inicios del siglo XVI, empezaban a estar cada vez más presentes en el análisis de la devoción femenina.

\section{El episodio de Juana de la Cruz}

Teniendo en cuenta lo expuesto, me gustaría analizar ahora un episodio que aparece repetido en dos manuscritos (en la Vida y fin, ff. 119v-121r, y el Libro de la casa, ff. 44r-48r), reiteración que señala su importancia por no ser precisamente común, ya que se da solo en escenas de relevancia para la teología de Juana como la de la lucha de ángeles y demonios (Sanmartín Bastida 2018).

En este relato de Juana de la Cruz, que adjunto en el apéndice de este artículo en su versión de la Vida y fin (por creerla anterior a la del Libro de la casa, donde se incluyen anécdotas de monjas posteriores), esta santa viva decide si la

14 Fray Melchor, el profeta de la aristocracia burgalesa que fue denunciado en 1512 al cardenal Cisneros por el franciscano fray Andrés, escribió a Juana en busca de una virgen sin mancilla para compartir su misión; ella remitió entonces la carta al Custodio de la Orden, fray Antonio Pastrana, quien a su vez la envió a Cisneros (Gómez López y García de Andrés 1982: 32-33). Para el posicionamiento de Juana frente a alumbrados, erasmistas y luteranos, y la visión de ella que tienen los censores tras su muerte, véase García de Andrés (1994: 6-8 y 14-15). Para un panorama general de las tendencias espirituales de la primera mitad del XvI sigue siendo imprescindible, aunque se hayan aportado datos nuevos, la monografía de Bataillon (1998), publicada primero en 1950. 
modificación de una escultura milagrosa (un entallador la renueva el gesto y el pecho) motiva una pérdida de su fuerza o poder. La transformación de la talla (y en este caso había sido previamente bendecida por el obispo y obrado milagros) preocupa porque la indisponibilidad o destrucción de una imagen, como nos recuerda el antropólogo Francesco Faeta (2016: 25), podía suponer la suspensión o transformación de la celebración. Quizás por esto y por la supuesta fealdad que había adquirido las compañeras de Juana estén tan disgustadas, lo que lleva a la franciscana, gran defensora del poder salvador de las imágenes, a regañarlas ${ }^{15}$. Juana tiene entonces una revelación donde la talla reformada adquiere una nueva autoridad que hace ahuyentar a los demonios. Es decir, Juana se convierte en una nueva mediadora entre la divinidad y la comunidad, en una función paralela a la de la Virgen, Dios y el sacerdote, y ella será quien permita y decida que esa imagen tenga igual o incluso más validez que la anterior.

Pero para ello primero tiene una visión en la que la Virgen se sitúa sobre la imagen y la acepta como morada, si bien a Juana esto no le basta y le pide que entre dentro de la misma para que la gente crea en su poder. La Virgen entonces pide la bendición y consagración de la imagen y la noche siguiente Juana ve a Dios llegar rodeado de un coro celestial para bendecir la escultura, vestido con ropas pontificales, como de obispo (es decir, renueva la bendición previa, pero esta vez dada directamente por él y no por un emisario). Pero antes de esa bendición la imagen es desnudada de sus sedas y, tras las antífonas a ella dirigidas, es vestida y puesta en su altar dejando a los demonios expresar su rabia con gritos y aullidos, tras lo cual el Señor desaparece rociando la casa con agua bendita. Entonces Juana, cuando vuelven sus compañeras a la celda, defiende el poder de las imágenes en la Iglesia y les cuenta la revelación.

Seguramente, el impulso dado a las imágenes al que me referí en el anterior epígrafe, dentro de esa política iniciada por los Reyes Católicos, y una estrategia de oposición a los grupos heréticos, es lo que hay detrás de estas palabras de Juana:

Lo que ay que deçir es que Nuestro Señor Dios tiene en tanto las ymágenes y se sirve que las aya en la sancta madre Yglesia, y que sean honradas y beneradas por nosotros peccadores, pues el mesmo Dios de los Çielos vino a la vendeçir y a enseñarnos cómo son cosa por donde se alcança virtud y devoçión quando se tiene en el coraçón. Y bien se pareze, según yo vi en una revelaçión que el Señor fue servido de me mostrar, quánto Él ama y honra la sancta madre Yglesia y a sus sanctas ymágines por amor della (Vida y fin, ff. 120v-121r; véase Libro de la casa, f. 47r-v).

15 Un episodio reivindicador del poder de las imágenes es el de su visión de un toro que lleva un alma y una imagen: es esta imagen santa, que le fue dada al alma para su consuelo y «defendimiento» por los ruegos de Juana (y que es la pintura de un santo a quien guarda devoción), la que le ayuda tras su muerte (Vida y fin, f. 110r). 
Procede entonces Juana a defender la importancia de limpiar el alma, como se ha limpiado el madero que contenía la imagen de la Virgen bendecida. Así pues, las almas, al igual que las imágenes, deben aparecer puras ante el Señor. Esta pureza y dignidad, junto con la desnudez con la que se presenta la Virgen, podemos conectarla con la Inmaculada, un dogma rubricado por las antífonas que se pronuncian y muy presente, por lo demás, en sus sermones (véase, especialmente, el de la Natividad: Juana de la Cruz 1999, I: 1.150-1.151), con lo cual este episodio adquiere nuevas connotaciones ${ }^{\mathbf{1 6}}$. Aunque proporcionar vestidos a las imágenes y a las almas es un rito repetido en las revelaciones femeninas (Vida y fin, ff. 75v-76r), la desnudez previa de María tiene connotaciones doctrinales. Recordemos que esa desnudez, que aparece en varios sermones de Juana, era un símbolo básico de la mística franciscana de la época (Triviño 2005: 49-50; García de Andrés 2012: 177-178), y Juana abunda en sus textos en este tema, además de en la necesaria limpieza del vestido que debe acompañar a las almas buenas o a los seres celestiales (Juana de la Cruz 1999, I: 1.422-1.423). Lo interesante es que, como asegura Ruiz-Gálvez (2008: 211-222), el asunto de la no «mácula» de la Virgen se mezcló, a partir del siglo XIV, con prejuicios antijudaicos reflejados en la limpieza de sangre que afectaban a los conversos: es decir, tenía unas connotaciones que podrían recordar las mujeres que oían las palabras de Juana.

El episodio termina con las monjas llevando la talla en procesión de vuelta al altar acostumbrado, tras esta arenga tan significativa de Juana citando a su ángel de la guarda, Laurel:

Bendito sea Dios en sus dones, e los sanctos en sus obras, y las ymágenes en sus altares, y los altares en sus yglesias, y las yglesias en sus sacramentos, y los sacramentos en la cruz y Passión de Nuestro Señor Jesuchristo, y en el sancto baptismo y remisión de los peccados (Vida y fin, f. 121r; véase Libro de la casa, f. 48r).

Como colofón, el Libro de la casa presenta un pasaje que no aparece en la Vida y fin, y que añade una manipulación divina de la imagen en sí:

[...] y dixo el Señor a la santa Juana, al tiempo de consagrar la imagen: "Diles a las monjas que traigan cuentas y se las pongan a mi Madre". Y ansí se hizo y estas son las quentas que llamamos de la Consagración. Tenía esta santa imagen la boca abierta y el Señor con su mano se la cerró, y dexó señal en la barbilla y labio alto; y los ojos que tenía muy en alto le puso el Señor sus dedos y se los abajó como aora los tiene. Y esto todo lo veýa la santa Juana y lo dixo (Libro de la casa, f. 48r).

16 Para las implicaciones teológicas del dogma en Juana véase García de Andrés (1999: 128-130), Triviño (2006: 207-230), García de Andrés (2012: 166-182) y Graña Cid (2005: 121-125). No hay que olvidar que los franciscanos, frente a los dominicos, fueron grandes defensores de este dogma. 
De este modo, se nos presenta a Cristo como escultor, lo que sin duda otorgaba un mayor poder a esa imagen que estaba bajo sus manos. Por otro lado, la alusión a unas cuentas relaciona este episodio con el controvertido de las cuentas del rosario que se hacen milagrosas al ser bendecidas por Juana, referido en la biografía impresa de Antonio Daza (de 1610, y reeditada, con modificaciones, en 1613), quien dice basarse en testimonios notariales, episodio matizado por la siguiente biografía impresa de Pedro Navarro, de 1622 (García de Andrés 1999: 37-38 y 52-53). El caso es que esta imagen, con las cuentas asociadas que lleva la falda de la Virgen, otorga a partir de entonces gracias e indulgencias, como la de origen franciscano de la Porciúncula (Libro de la casa, ff. 43v-44r) ${ }^{17}$.

Aunque en la primera versión el toque a la escultura por parte de Cristo no es explícito, adoptando la distinción de la patrística griega podemos decir que, tras el trance, la imagen ha nacido «por generación», ganando valor frente a aquellas que provienen de una producción artificial o manufacturada (cada vez más frecuentes, por cierto, en el mercado de imágenes), una distinción muy importante en la polémica anti-idolátrica del periodo iconoclasta (Pereda 2007: 128). Como se dice en los versos de una antífona que solo aparecen en la Vida y fin (f. 120v), la imagen es ahora fabricada por la mano de Cristo, ya no por la del hombre.

Pero a nosotros nos interesa especialmente el establecimiento de una cadena de autorizaciones sobre la imagen cuyo eslabón último es Juana (a través de su revelación), tras la de la Virgen posándose sobre ella y la bendición de Cristo. Y si la imagen es la depositaria de la autorización que encabeza Juana, esta de algún modo se beneficia de la virtus desprendida (mediante el contacto visual) por el objeto contemplado (Pereda 2007: 122) ${ }^{\mathbf{1 8}}$. De este modo, la autorización de la mujer se produce en esta interacción con la imagen mediante su igualación en el espacio y el tiempo del trance: el proceso sobrenatural ha afectado a ambas otorgándoles mayor autoridad. Hablamos entonces no de una iconografía inspiradora, sino de carismas intercambiables. Juana se apropia aquí de la función sacerdotal de autorizar a las imágenes a ser objetos de devoción, imitando la intención de la Virgen cuando se posa sobre la escultura que se pone en cuestión. Juana, quien,

17 El hecho de que la edición de 1613 de Daza y la hagiografía de Navarro de 1622 disociaran la concesión de indulgencias de las cuentas (por problemática) nos indica que a la fuerza la redacción del Libro de la casa tuvo que ser anterior. Yo creo que se debió de componer en la segunda mitad del siglo xvi: hacia finales de esta centuria la devoción de las cuentas estaba ya muy difundida (García de Andrés 1999: 37).

18 Esto no debe sorprendernos si tenemos en cuenta que teólogos como Alonso de Espina, uno de los instigadores fundamentales de la creación de la Inquisición, en su Fortalitium fidei (obra impresa por primera vez en 1471 y que se constituye en toda una diatriba contra la raza judía) había llegado a defender que las imágenes no solo representan a la divinidad sino que la contienen (Pereda 2007: 109, 114-116; fragmento de la obra reproducido en 410-417). 
como otras visionarias de su época, otorga a la Virgen una cualidad sacerdotal, la extiende hacia sí misma en este episodio, aunque busque el refrendo de la bendición de Cristo sobre la imagen. Esta autorización sobre la imagen (Juana a la vez adquiere autoridad a partir de la imagen y autoriza a la imagen a circular) le otorga independencia con respecto a los sacerdotes, que no tienen papel en el proceso. De hecho, es Cristo mismo, vestido como obispo, quien bendice a la imagen, frente a la primera vez en que lo hizo un obispo terrenal (en la anterior, y por tanto más imperfecta, versión de María). Y hay que recordar aquí que era esta una acusación frecuente a las visionarias: su autonomía frente al clero, manifestada también en las ocasiones en que tomaban la comunión directamente de mano de los ángeles o de Dios mismo. Una autonomía en la que les precedía la Virgen, presentada muchas veces como sacerdote en las revelaciones: un motivo especialmente privilegiado en los sermones de Juana (Juana de la Cruz 1999, I: 369-370; Triviño 2006: 57-83), y, en general, en las visionarias, y que se veía justificado por esa Virgen contenedora de la eucaristía de las artes visuales, recurrente a partir del IV Concilio de Letrán (Mocholí Martínez 2016: 478-479). En el episodio, el dogma de la Inmaculada refuerza la percepción del poder de la imagen, situándose del lado de Juana, la Inquisición, la Iglesia (sus pies son los cimientos de la misma: Vida y fin, f. 120v; Libro de la casa, f. 46v) y la política regia citada en el anterior apartado.

Teniendo en cuenta que Juana de la Cruz de algún modo ejerció una labor sacerdotal al hacerse cargo de la parroquia de Cubas (Graña Cid 2004), y que «the very existence of a sermon-book is a dramatic reminder of Juana's appropiation of the priestly, and therefore masculine, role of preacher» (Surtz 1990: 6), que Ronald Surtz interpreta desde una cierta androginia (1990: 7), no nos extraña que esta asunción de autoridad espiritual fuera aceptada por el público de sus revelaciones $y$, en última instancia, por una memoria colectiva femenina responsable de unas obras que (hay que decirlo) nunca llegaron a imprimirse ${ }^{19}$. Finalmente, si, como dije en una ocasión (Sanmartín Bastida 2016: 196), en la obra de Juana se apuesta por la disolución de la dicotomía del género (lo cual contrasta con la exaltación de la mujer que se ha tendido a leer en su texto), su relación con las imágenes corrobora que esta distinción no es un elemento significativo para Juana, como se ve en la autoridad que se ejerce sobre ellas por parte de Cristo, la Virgen, Juana o el clero, igualados todos en la labor de proporcionar poder a las imágenes.

19 Por razones de espacio, no nos ocuparemos de esta apuesta por la lectura andrógina de Juana, basada en que en el vientre de su madre se cambió su sexo y se convirtió de hombre a mujer, lo cual le dejó de huella tras su nacimiento una nuez masculina (Vida y fin, ff. 2r-3r). La androginia de la teología de Juana es problematizada por Boon (2018), quien apuesta por aplicar el término transgénero tanto a la autora como a sus personajes. 


\section{BiBLIOGRAFÍA}

Bataillon, Marcel (1998). Erasmo y España: Estudios sobre la historia espiritual del siglo XVI. Ciudad de México: Fondo de Cultura Económica.

BeLting, Hans (2009). Imagen y culto: Una historia de la imagen anterior a la era del arte. Madrid: Akal.

Boon, Jessica (2018). «At the Limits of (Trans)Gender: Jesus, Mary, and the Angels in the Visionary Sermons of Juana de la Cruz (1481-1534)». Journal of Medieval and Early Modern Studies, 48.2, pp. 261-300.

Braguier, Laurey (2014). Recherches sur les beatas de la Couronne de Castille: Étude prosopographique, pratiques spirituelles et implication sociale (1450-1600). Ricardo Saez (dir.) [tesis doctoral]. Rennes: Université Rennes $2<\mathrm{http}$ :/www. worldcat.org/search?q=no\%3A903119157> [Consulta: 10/02/2019].

CONDE Solares, Carlos (2017). El canon heterodoxo de la gran mística hispánica: beatas, meditación e iluminismo. Oviedo: Universidad de Oviedo.

Connor, Steven (2000). Dumbstruck: A Cultural History of Ventriloquism. Oxford: Oxford University Press.

Cortés Timoner, María del Mar (2004). Sor Juana Inés de la Cruz (1481-1534). Madrid: Ediciones del Orto.

Cruz, Anne J. (2005). «La sororidad de Sor Juana: espiritualidad y tratamiento de la sexualidad femeninas en España y el Nuevo Mundo». En Lisa Vollendorf (ed.), Literatura y feminismo en España (s. XV-XXI). Barcelona: Icaria Editorial, pp. 95106.

Duby, Georges (1995). Art et société au Moyen Âge. Paris: Éditions du Seuil.

Elliot, Dyan (2004). Proving Woman: Female Spirituality and Inquisitional Culture in the Later Middle Ages. Princeton: Princeton University Press.

FAETA, Francesco (2016). Fiestas, imágenes, poderes: Una antropología de las representaciones. A. Gorka Aguirre (trad.). Vitoria-Gasteiz: Sans Soleil.

FreedBerg, David (1992). El poder de las imágenes: Estudios sobre la historia y la teoría de la respuesta. Madrid: Cátedra.

GARCía AvilÉs, Alejandro (2007). «Imágenes 'vivientes'. Idolatría y herejía en las Cantigas de Alfonso X el Sabio». Goya. Revista de Arte, 321, pp. 324-342.

GARCÍA DE ANDRÉs, Inocente (1994). «La Santa Juana, grande y legítima maestra franciscana». Verdad y Vida: Revista de las Ciencias del Espíritu, 52, pp. 227-256.

GARCía DE ANDRÉs, Inocente (1999). «Introducción», en su ed. Juana de la Cruz, El Conhorte: Sermones de una mujer. La Santa Juana (1481-1534). Salamanca: Fundación Universitaria Española/Universidad Pontificia de Salamanca, I, pp. 13-223.

García DE ANDrÉs, Inocente (2012). Teología y Espiritualidad de la Santa Juana: Una mujer predicadora. Madrid: Edibesa.

Gell, Alfred (1998). Art and Agency: An Anthropological Theory. Oxford: Clarendon.

Giles, Mary E. (1990). The Book of Prayer of Sor Maria of Santo Domingo: A Study and Translation. Albany: State University of New York Press. 
Gómez LóPez, Jesús e Inocente García de Andrés (1982). Sor Juana de la Cruz: mística e iluminista toledana. Toledo: Diputación Provincial.

Graña CID, María del Mar (2004). «El cuerpo femenino y la dignidad sacerdotal de las mujeres: Claves de autoconciencia feminista en la experiencia mística de Juana de la Cruz (1481-1534)». En Pedro Rodríguez Panizo, Secundino Castro Sánchez y Fernando Millán Romeral (eds.), Umbra, imago, veritas: homenaje a los profesores Manuel Gesteira, Eusebio Gil y Antonio Vargas-Machuca. Madrid: Universidad Pontificia Comillas, pp. 305-338.

Graña Cid, María del Mar (2005). «La Inmaculada Concepción de María y la Teología Feminista Hispana en el Renacimiento». Verdad y vida: Revista de las Ciencias del Espíritu, 63.243-244, pp. 113-126.

GraÑa Cid, María del Mar (2009). «La feminidad de Jesucristo y sus implicaciones eclesiales en la predicación mística de Juana de la Cruz (Sobre la Prerreforma y la Querella de las Mujeres en Castilla)». Estudios Eclesiásticos, 84.330, pp. 477-513.

Hayes, Mary (2011). Divine Ventriloquism: Power, Anxiety, Subversion. New York: Palgrave Macmillan.

JäGGI, Carola (2014). «Dialogar con Dios: El uso de las imágenes en los conventos femeninos de dominicas en la Teutonia bajomedieval». Anuario de Estudios Medievales, 44.1, pp. 241-276.

Juana de la Cruz (1999). El Conhorte: Sermones de una mujer. La Santa Juana (14811534). Inocente García de Andrés (ed.). Salamanca: Fundación Universitaria Espanola/ Universidad Pontificia de Salamanca, 2 vols.

Libro de la casa y monasterio de Nuestra Señora de la Cruz. BNE ms. 9.661. María Victoria Curto (ed.). En Rebeca Sanmartín Bastida y Ana Rita Soares (eds.) (2018), Catálogo de Santas Vivas. Madrid: Universidad Complutense de Madrid, 2018 $<$ http://catalogodesantasvivas.visionarias.es/index.php/Juana_de_la_Cruz\#Vida manuscrita>.

Luengo Balbás, María (2016). Juana de la Cruz: Vida y obra de una visionaria del siglo $X V I$. Rebeca Sanmartín Bastida (dir.) [tesis doctoral]. Madrid: Universidad Complutense de Madrid. <https://eprints.ucm.es/39518/> [Consulta: 02/02/2019].

Mocholí Martínez, María Elvira (2016). Las imágenes conceptuales de María en la escultura valenciana medieval. Rafael García Mahíques (dir.) [tesis doctoral]. València: Universitat de València. <http://roderic.uv.es/handle/10550/57144> [Consulta: 02/02/2019].

Muñoz Fernández, Ángela (1994). Santas y beatas neocastellanas: Ambivalencias de la religión y politicas correctoras del poder (siglos XIV-XVII). Madrid: Dirección General de la Mujer de la CAM/Instituto de Investigaciones Feministas de la Universidad Complutense.

Muñoz FernÁNDEZ, Ángela (2014a). «Las mujeres como ‘criaturas permanecientes'. Género y diferencia sexual a la luz de las narrativas de la creación en la obra de Juana de la Cruz (1481-1534)». En Nieves Baranda y M. ${ }^{a}$ Carmen Marín Pina (eds.), Letras en la celda: cultura escrita de los conventos femeninos en la España moderna. Madrid/Frankfurt am Main: Iberoamericana/Vervuert, pp. 207-220. 
Muñoz Fernández, Ángela (2014b). «El linaje de Cristo a la luz del 'giro genealógico' del siglo xv: La repuesta de Juana de la Cruz (1481-1534)». Anuario de Estudios Medievales, 44.1, pp. 433-473.

Pereda, Felipe (2007). Las imágenes de la discordia: Politica y poética de la imagen en la España del 400. Madrid: Marcial Pons.

Sanmartín Bastida, Rebeca (2012). La representación de las místicas. Sor María de Santo Domingo en su contexto europeo. Santander: Real Sociedad Menéndez Pelayo.

SANMARTín BAStidA, Rebeca (2015). «En torno al arte y las visionarias». Medievalia, 18.2, pp. 355-365.

SANMARTín BASTIDA, Rebeca (2016). «Sobre las categorías de santa, beata y visionaria: El género performativo». Cahiers d'Études Hispaniques Médiévales, 39, pp. 183 203.

SANMARTín BASTIDA, Rebeca (2018). «La puesta en escena de la historia sagrada a comienzos del siglo Xvi: La batalla de los ángeles en la dramaturgia visionaria de Juana de la Cruz». Renaessanceforum: Tidsskrift for Rencessanceforskning: Journal of Renaissance Studies, 13, pp. 185-210.

SANMARTín BASTIDA, Rebeca (en prensa). «Performing Authority through Iconography: On Iberian Visionary Women and Images». En Michael Gerli and Ryan Giles (eds.). The Routledge Companion to Medieval Iberia. London/New York: Routledge.

SANTONJA, Pedro (2000). «Las doctrinas de los alumbrados españoles y sus posibles fuentes medievales». Dicenda, 18, pp. 353-392.

SASTRE VARAs, Lázaro (2004). «Fray Jerónimo de Ferrara y el círculo de la Beata de Piedrahíta». En Júlia Benavent, Inés Rodríguez y Daniel Weinstein (eds.), La figura de Jerónimo Savonarola O.P. y su influencia en España y Europa. Firenze: Edizioni del Galluzzo per la Fondazione Ezio Franceschini, pp. 169-195.

Schmitт, Jean-Claude (1990). La raison des gestes in l'Occident médiéval. Paris: Gallimard.

Surtz, Ronald E. (1990). The Guitar of God: Gender, Power, and Authority in the Visionary World of Mother Juana de la Cruz (1481-1534). Philadelphia: University of Pennsylvania Press.

Surtz, Ronald E. (1995). Writing Women in Late Medieval and Early Modern Spain: The Mothers of Saint Theresa of Avila. Philadephia: University of Philadelphia Press.

Triviño, María Victoria (2005). Mujer, predicadora y párroco: La Santa Juana (14811534). Madrid: Biblioteca de Autores Cristianos.

Triviño, María Victoria (2006). Inspiración y ternura: Sermones marianos de la Santa Juana (1481-1534). Presentación de Mons. Antonio Cañizares. Madrid: Biblioteca de Autores Cristianos.

Vida de la bienabenturada virgen María de Ajofrín (2018). Ms. Esc. C-III-3, ff. 192r-232v. Celia Redondo Blasco (ed.). En Rebeca Sanmartín Bastida y Ana Rita Soares (eds.), Catálogo de Santas Vivas. Madrid: Universidad Complutense de Madrid $<\mathrm{http}$ :/catalogodesantasvivas.visionarias.es/index.php/María_de_Ajofrín\#Vida_ manuscrita_.281.29>. 
Vida y fin de la bienabenturada virgen sancta Juana de la Cruz. Ms. Esc. K-III-13, ff. $1 \mathrm{r}-137 \mathrm{r}$.

ZARRI, Gabriella (1990). Le sante vive: profezie di corte e devozione femminile tra '400 e '500. Torino: Rosenberg \& Sellier.

\section{APÉNDICE \\ [Vida y fin de la bienabenturada virgen sancta Juana de la Cruz, Esc. K-III-13, ff. $119 \mathrm{v}-121 \mathrm{r}]^{20}$. \\ Capítulo 26: \\ «DE UNA REVELACIÓN QUE VIO ESTA BIENABENTURADA TOCANTE A UNA IMAGEN»}

Tienen e[n] tal monasterio de sancta María de la Cruz una ymagen de Nuestra Señora, la qual hera de bulto muy antigua, y las monjas, saviendo que la havía bendeçido un obispo, tiénenla mucha devoçión porque algunas vezes la havían visto hazer milagros y sacábanla en proçesión los días del Sancto Apareçimiento. Y por ser tan antigua renováronle el gesto por un entallador, cortándole de la garganta arriva, y pusiéronle otro gesto y pecho. Y trayéndola al monasterio fueron las monjas a la ver e saludar y algunas les pareçió muy bien y se consolaron con ella, y a otras les pareçió mexor el gesto que antes tenía y desconsoláronse mucho de manera que vinieron en alguna diferençia de palabras. Y saviéndolo esta bienabenturada, mandolas llamar y díxoles: «Muy maravillada estoy, hermanas mías, de la desconsolaçión que tenéys del renovamiento de esta sancta ymagen, dado caso aya razón por la falta de la ymperfeçión de la pintura no ser tan aplaçiente a nuestros ojos; pero, aunque sean feas las ymágenes, es cargo de conçiençia no tenerlas en mucha reverençia y estima, en espeçial si son las tales ymágenes de Dios y de Nuestra Señora, que estas tales, feas o hermosas, son dignas de muy grande acatamiento. E ruégoos, señoras, hagáys aquí un altar en esta nuestra çelda y traed aquí la sancta ymagen, aunque yo sea indigna dello, que si yo pudiese ya avría ydo al coro de rodillas a saludar a su Alta Magestad».

Y, traýda la ymagen a la çelda de la sancta virgen y puesta en el altar, rogolas que la dexasen allí dos días, y, estando ella aquella noche en contemplaçión, vido a Nuestra Señora en visión muy hermosíssima, y poníase enzima de la ymagen suya y dezía: "Yo me contento de esta ymagen y la escogo y açeto para mi

20 Recojo la edición de este capítulo de Luengo Balbás (2016: 531-535), enmendando algunas lecturas por mi cotejo con el manuscrito original. En breve se publicará una edición de esta vida en el Catálogo de Santas Vivas que edita el proyecto mencionado al comienzo de este artículo. El capítulo es más largo de lo que aquí aparece pero solo se trata nuestro episodio en los folios aquí transcritos. 
morada y aposento, y como en trono mío resplandezco en ella y en mi spíritu se [f. 120r] goza porque los peccadores conmigo abrán refrigerio y consolaçión y yo les ganaré del mi Hijo perpetuo gozo en la gloria perdurable». Y esta bienabenturada, que lo veýa, suplicava a Nuestra Señora que entrase dentro de la ymagen su spíritu pues hera tan hermosa, y dende allí escuchase las oraçiones que le hazían y en espeçial las suyas, porque ella viese que no caýa en vaçío hechas delante su preçiosa ymagen como algunas vezes tienen las gentes crédito, que no está allí donde la llaman. A los quales pensamientos y suplicaçiones respondió Nuestra Señora y dixo: «Por estar nuevamente puesto este madero en esta ymagen mía, no quiere Dios ni a mí plaze entrar dentro en ella hasta que se consagre o vendiga de manera que se haga digna e perteneçiente de mí por virtud de la consagraçión justa que devidamente deven tener las ymágines e yglesias enteras, y altares aparejados y limpios al culto divino».

Y la noche siguiente vido la bienabenturada a ora de los maytines una visión muy gloriosa, y es que vido venir a Nuestro señor Dios en un trono muy rico en bestiduras pontificales çercado y acompañado de muchedumbre de ángeles y sanctos y sanctas, y estava junto a la dicha ymagen de Nuestra Señora, a la qual bendeçía con palabras muy devotas e reverençiales y cantares y dulçes sones que hazían los ángeles con diversos ynstrumentos, de las quales palabras y cançiones no pudo colegir esta bienabenturada sino pocas palabras, y el día que vido esta revelaçión hera octava de la dedicaçión de la yglesia, y las çeremonias que Nuestro Señor hizo en la consagraçión de esta sancta ymagen fueron muchas. Estava bestido como obispo, y la ymagen, que estava bestida de sedas, según es uso adereçar las ymágines, a deshora pareçió toda desnuda y alçada en alto teniéndose con el poder de Dios. Esto hera antes que el Señor la bendixese, el qual día hizo llamamiento a los sanctos ángeles para que viesen lo que hazía en aquella ymagen y assimismo los demonios para que huviesen miedo y viesen la virtud que Dios ponía en su sancta Yglesia e ymágenes y altares. E por fuerça se lo hazían mirar y reverençiar, que dava poderío a la sancta madre Yglesia que vençiese ella al demonio, e deshechase con baldón, y resçiviese a Dios Jesuchristo y a su sancta Madre con reverençia e honor, e para esto bendeçía y deçía a altas vozes el mesmo Señor desde su alto trono: «'Ego sum quis me ${ }^{21}$, et ecce nova facio omnia", que quiere dezir: "Yo [f. 120v] soy [Y]abé, que todas las cosas hago nuevas. En lo alto del çielo moro, soy rey eterno que rixo los coraçones cathólicos y devotos; el mi adversario los perturba, empero yo soy el que los asosiego; él los derrama, yo los allego; y él los disipa, yo los proqueo; él los destruye, yo los edifico;

21 En un mal latín (debería ser «Ego sum qui sum»), se alude a la contestación de Dios que recibió Moisés cuando preguntó la identidad de quien hablaba desde la zarza ardiente: «Yo soy Él que soy» (Éxodo 3: 14). 
él los ensuçia, yo los alimpio; él los enturbia y revuelve y haze oler mal, yo los purifico y hago bien oler suavíssimo. Sé de lo malo hazer bueno y de lo no limpio hazer limpio, y de lo ymperfeto hazer perfeto, e loable y agradable». Y volvía sus preçiosos ojos a la ymagen de Nuestra Señora, e dezía: «¿Quién te deçía madre mía?»; e poníale muchas cruzes hechas joyeles. Estando ella ansí desnuda la çercava toda, espeçialmente la caveça, frente y gesto, y los pechos y espaldas e hombros, y braços y manos, con todo el cuerpo hasta los pies, que significavan los çimientos de la sancta madre Yglesia, y después de muchas bendiçiones que el Señor deçía, dixo cantando aquella antíphona que dize: «Hanc quam tu despicies, Maniche, \& mater mea est, \& de manu mea fabricata ${ }^{22}$.

Y respondían los ángeles con muy claras vozes, diziendo: «Fons hortorum, redundans gratia mundum, replens celi numeribus, mater Dei fecundans, omnia nos instamrans, supernis sedibus flores hortum, mox ab infantia, admirandus fulsit virtutibus, eam dian candens flos multiplicat virgule decorem, conceptus glorificat Maria pudorem $\rangle^{23}$. Y mientras estas antíphonas y cançiones se deçían, pareçió a deshora la ymagen de Nuestra Señora bestida de las mesmas bestiduras de muger y puesta en su altar como primero estava, y los demonios quedáronse mesando, y arañando, y dando gritos e aullidos, y la visión de Nuestro Señor desapareçió, roçiando la casa con agua bendita.

Y la bienabenturada quedó muy consolada. Y pasados los dos días que la sancta ymagen estava en su çelda, ayuntáronse allí el abbadesa y monjas, diziendo a la sancta virgen que yban por la ymagen, ymportunándola el abbadesa que, pues estavan allí todas, les dixese alguna cosa de las que Dios les mostrava. Respondió diziendo: «Lo que ay que deçir es que Nuestro Señor Dios tiene en tanto las ymágenes y se sirve que las aya en la sancta madre Yglesia, y que sean honradas y beneradas por nosotros peccadores, pues el mesmo Dios de los Çielos vino a la [f. 121r] vendeçir y a enseñarnos cómo son cosa por donde se alcança virtud y devoçión quando se tiene en el coraçón. Y bien se pareze, según yo vi en una revelaçión que el Señor fue servido de me mostrar, quánto Él ama y honra la sancta

$\overline{22} \quad$ Esta cita no aparece en el episodio del Libro de la casa. El latín de la transcriptora parece muy deficiente; proviene de la frase: «Hanc, quam tu despicis, Manichee, mater mea est, et de manu mea fabricata», sita en una de las antífonas de Vísperas de la Misa de la Inmaculada Concepción del Oficio Divino, que sigue una tradición franciscana; la frase se atribuye a san Agustín.

23 Parece también esta la escritura de una persona (¿María Evangelista?) que no sabe latín: se trata de dos fragmentos de antífonas del Breviario Romano, de la Fiesta de la Visitación de la Virgen, la primera de Vísperas y la segunda de los Maitines: «Fons hortorum, redundans gratia mundum, replens coeli numeribus, mater Dei foecundans, omnia nos instauras, supernis sedibus florens hortus mox ab infantia, admirandis fulsit virtutibus»; «Candens flos multiplicat virgula decorem; conceptus glorificat Maria pudorem». En el Libro de la casa (ff. 46v-47r), falta el fragmento «coeli numeribus, mater Dei foecundans, omnia nos instauras». 
madre Yglesia y a sus sanctas ymágines por amor della». Y dixo la revelaçión susodicha, y añidió diziendo: «Me dixo mi sancto ángel, después que desapareçió el Señor: 'Mira qué son las maravillas de Dios, que si en un madero alla Dios bescosidad, y no quiere que su sancta madre le quiera y tenga por su ymagen hasta le haver alimpiado y puesto en él dignidad de bendiçión suya como la tiene la sancta Yglesia, ¿qué tales estarán las ánimas, que llenas de pecados están ensuçiadas y asquerosas?, ¿cómo serán dignas aquellas tales que venga Dios en ellas, ni su sancta madre con graçia y piadosa caridad, si primero no son alimpiadas las tales ánimas peccadoras por espeçial graçia de Spíritu Sancto, sin el qual ninguna cosa es buena, ni justa, ni sancta, ni digna, ni açepta a Dios? Y por semejante, con los dones del sancto spíritu, las cosas que son d'Él preçiadas e baxas Dios las ensalça y tiene en ellos thesoros muy grandes, aunque ascondidos a los ojos de las personas de la Tierra. Bendito sea Dios en sus dones, e los sanctos en sus obras, y las ymágenes en sus altares, y los altares en sus yglesias, y las yglesias en sus sacramentos, y los sacramentos en la cruz y Passión de Nuestro Señor Jesuchristo, y en el sancto baptismo y remisión de los peccados». Y acavado esto, dixo la bienabenturada: «Bien se pueden llevar la sancta ymagen». La qual llevaron el abbadesa y monjas con mucha devoçión y reverençia con candelas ençendidas, cantando el «te deum laudamus» al coro. Y la pusieron en el altar acostumbrado y, de aý adelante, se consolaron mucho las monjas con esta ymagen.

Recibido: 08/03/2019

Aceptado: 20/04/2019 


\section{雾}

UN EPISODIO EN LA VIDA DE LA VISIONARIA JUANA DE LA CRUZ:

SOBRE LA AUTORIDAD ESPIRITUAL FEMENINA A COMIENZOS DEL SIGLO XVI

RESUMEN: Este artículo quiere dar a conocer un episodio que tuvo mucha importancia en la vida de la visionaria Juana de la Cruz, ya que aparece repetido en dos manuscritos: en su hagiografía y en el Libro de la casa de su comunidad. A partir de esta escena, donde Juana muestra su poder sobre la escultura de una Virgen al autorizarla como objeto de devoción, se abordarán las relaciones entre la mujer visionaria, su autorización espiritual, las imágenes, la doctrina de la Inmaculada y, finalmente, los grupos herejes. La primera versión del episodio es reproducida como apéndice del artículo.

Palabras Claves: Juana de la Cruz, autoridad espiritual femenina, siglo XVI, imágenes.

\section{AN EPISODE IN THE LIFE OF THE VISIONARY JUANA DE LA CRUZ: ON FEMALE SPIRItUal AUthority IN the BEGINNING OF THE $16^{\text {TH }}$ CENTURY}

ABSTRACT: This article aims to give insight into an episode that was very important in the life of the visionary Juana de la Cruz, since it appears in two manuscripts: in her vita and in the Libro de la casa of her convent. Analyzing this scene - where Juana shows her power over a sculpture of the Virgin by authorizing it to function as an object of devotionallows us to draw out some conclusions on the relationships between visionary women, spiritual authority, images, the doctrine of the Inmaculate Conception, and, eventually, heretic groups. The first version of this episode is reproduced here as an appendix to the article.

Keywords: Juana de la Cruz, female spiritual authority, $16^{\text {th }}$ century, images. 